\title{
Plant surface reactions: an opportunistic ozone defence mechanism impacting atmospheric chemistry
}

\author{
W. Jud ${ }^{1}$, L. Fischer ${ }^{1}$, E. Canaval ${ }^{1}$, G. Wohlfahrt ${ }^{2,3}$, A. Tissier ${ }^{4}$, and A. Hansel ${ }^{1}$ \\ ${ }^{1}$ Institute of Ion and Applied Physics, University of Innsbruck, 6020 Innsbruck, Austria \\ ${ }^{2}$ Institute of Ecology, University of Innsbruck, 6020 Innsbruck, Austria \\ ${ }^{3}$ European Academy of Bolzano, 39100 Bolzano, Italy \\ ${ }^{4}$ Leibniz Institute of Plant Biochemistry, Department of Cell and Metabolic Biology, 06120 Halle, Germany \\ Correspondence to: A. Hansel (armin.hansel@uibk.ac.at)
}

Received: 3 June 2015 - Published in Atmos. Chem. Phys. Discuss.: 21 July 2015

Revised: 3 December 2015 - Accepted: 13 December 2015 - Published: 18 January 2016

\begin{abstract}
Elevated tropospheric ozone concentrations are considered a toxic threat to plants, responsible for global crop losses with associated economic costs of several billion dollars per year. Plant injuries have been linked to the uptake of ozone through stomatal pores and oxidative damage of the internal leaf tissue. But a striking question remains: can surface reactions limit the stomatal uptake of ozone and therefore reduce its detrimental effects to plants?

In this laboratory study we could show that semi-volatile organic compounds exuded by the glandular trichomes of different Nicotiana tabacum varieties are an efficient ozone sink at the plant surface. In our experiments, different diterpenoid compounds were responsible for a strongly varietydependent ozone uptake of plants under dark conditions, when stomatal pores are almost closed. Surface reactions of ozone were accompanied by a prompt release of oxygenated volatile organic compounds, which could be linked to the corresponding precursor compounds: ozonolysis of cis-abienol $\left(\mathrm{C}_{20} \mathrm{H}_{34} \mathrm{O}\right)$ - a diterpenoid with two exocyclic double bonds - caused emissions of formaldehyde ( $\mathrm{HCHO}$ ) and methyl vinyl ketone $\left(\mathrm{C}_{4} \mathrm{H}_{6} \mathrm{O}\right)$. The ring-structured cembratrien-diols $\left(\mathrm{C}_{20} \mathrm{H}_{34} \mathrm{O}_{2}\right)$ with three endocyclic double bonds need at least two ozonolysis steps to form volatile carbonyls such as 4-oxopentanal $\left(\mathrm{C}_{5} \mathrm{H}_{8} \mathrm{O}_{2}\right)$, which we could observe in the gas phase, too.

Fluid dynamic calculations were used to model ozone distribution in the diffusion-limited leaf boundary layer under daylight conditions. In the case of an ozone-reactive leaf surface, ozone gradients in the vicinity of stomatal pores are
\end{abstract}

changed in such a way that the ozone flux through the open stomata is strongly reduced.

Our results show that unsaturated semi-volatile compounds at the plant surface should be considered as a source of oxygenated volatile organic compounds, impacting gas phase chemistry, as well as efficient ozone sink improving the ozone tolerance of plants.

\section{Introduction}

Tropospheric ozone $\left(\mathrm{O}_{3}\right)$ is formed as a product of photochemical reactions involving nitrogen oxides $\left(\mathrm{NO}_{x}\right)$ and volatile organic compounds (VOC) as precursors (Jenkin and Clemitshaw, 2000). Increasing anthropogenic precursor emissions from fossil fuel and biomass burning have led to elevated ambient ozone concentrations over large portions of the earth's surface. Today, many regions experience near-ground ozone background levels greater than 40 parts per billion volume (ppbv) (Vingarzan, 2004), levels which may be responsible for cellular damage inside leaves (Hewitt et al., 1990; Wohlgemuth et al., 2002), adversely affecting photosynthesis and plant growth (Ashmore, 2005). Toxic ozone concentrations cause visible leaf injury, plant damage, and reduction in crop yields with associated economic costs of several billion dollars per annum worldwide (Wang and Mauzerall, 2004; Van Dingenen et al., 2009). Future trends of tropospheric ozone strongly depend on the emission factors of the corresponding precursor compounds (i.e. VOC and $\mathrm{NO}_{x}$ ) and indirectly also on land cover and character- 
istics of the vegetation (Dentener et al., 2006; IPCC, 2013; $\mathrm{Fu}$ and Tai, 2015). Some recent studies revealed a stabilization or even a lowering of the tropospheric background ozone concentrations in parts of the industrialized western countries since the turn of the millennium (Logan et al., 2012; Parrish et al., 2012; Oltmans et al., 2013; IPCC, 2013). This is likely a result of preventive measures reducing ozone precursor emissions (Granier et al., 2011). In contrast, ozone background concentrations are still rising in parts of Asia experiencing high economic growth and a concomitant increase in $\mathrm{NO}_{x}$ emissions (Granier et al., 2011; Fu and Tai, 2015).

Land cover and land use changes, often determined by changing climatic conditions, could impact tropospheric ozone in different ways: a higher leaf area index of the vegetation would enhance dry deposition of ozone (Fu and Tai, 2015). In low $\mathrm{NO}_{x}$ regions enhanced emissions of isopreneemitting species could decrease ozone concentrations, while they would lead to an ozone increase in high $\mathrm{NO}_{x}$ regions (Fu and Tai, 2015).

Traditionally, the risk of ozone damage to plants is estimated on the basis of the accumulated ozone exposure above 40 ppbv (AOT 40) (Felzer et al., 2005). However, the negative effects of ozone on vegetation have been observed to be more closely related to the effective dose, i.e. the stomatal flux $\times$ time minus the portion of ozone which can be detoxicated by the plant defence system (Massman, 2004). In the expected $\mathrm{CO}_{2}$ richer and warmer future atmosphere (IPCC, 2013), plants may reduce stomatal conductance and thus indirectly alleviate ozone damage (Sitch et al., 2007).

However, accurate experimental quantification of the stomatal uptake of ozone is complicated by the presence of other ozone sinks, either in the gas phase or on the plant surface (Fruekilde et al., 1998; Cape et al., 2009). In previous studies the ozone flux through the stomata was calculated by multiplying the stomatal ozone conductance with the ambient ozone concentration (see, e.g. Kurpius and Goldstein, 2003; Cieslik, 2004; Goldstein et al., 2004; Fares et al., 2012), assuming similar gradient profiles of ozone and $\mathrm{H}_{2} \mathrm{O}$ close to the stomata. As we will show, for ozone-reactive leaf surfaces this approach is not fully correct and may lead to an overestimation of stomatal ozone uptake in the case of very reactive surfaces.

We present results from ozone fumigation experiments, in which intact leaves of different varieties of tobacco (Nicotiana tabacum) were exposed to elevated ozone levels (20$150 \mathrm{ppbv}$ ) under light and dark conditions in an exceptionally clean plant enclosure system (see Sect. 2 for experimental details). The Nicotiana tabacum species is famous for large differences in the ozone tolerance of the different varieties. For example, the $\mathrm{Bel} \mathrm{W3}$ is known to be very ozone sensitive (Heggestad, 1991; Loreto et al., 2001) and has therefore been used as an ozone indicator plant in earlier times (see Heggestad, 1991, and references therein). Conversely, the Bel B variety is known to be non-sensitive (Heggestad, 1991). The high ozone tolerance of this variety has been attributed to wider epidermal cells and more spongy mesophyll cell layers (Borowiak et al., 2010) and to differences in the plant's ability to cope with oxidative stress once ozone has entered the stomata (Schraudner et al., 1998; Eltayeb et al., 2007).

Several studies were investigating the possibility to increase the ozone tolerance of plants by external application of ozone-scavenging compounds (Gilbert et al., 1977; Loreto et al., 2001; Vickers et al., 2009a; Singh and Agrawal, 2010; Agathokleous et al., 2014) or by enabling the emission of volatile terpenoids in transgenic plants (Vickers et al., 2009b; Palmer-Young et al., 2015). We show here that some of the tobacco varieties investigated in our experiments are intrinsically equipped with ozone scavenging compounds located on their leaf cuticula. As is the case for many other plant species (Fahn, 1988), tobacco leaves possess glandular trichomes. In tobacco, various diterpenoids are the major compounds exuded by these secretory structures at the leaf surface (Sallaud et al., 2012). The exudates cover the plant leaves as a defence barrier, for example against arthropod pests (Wagner, 1991; Lin and Wagner, 1994); they were shown to have an anti-fungal (Kennedy et al., 1992) and insecticidal action (Kennedy et al., 1995). We show that in a tobacco variety secreting the diterpenoid $c i s$-abienol, the exudates have a beneficial side-effect: they act as a powerful chemical protection shield against stomatal ozone uptake by depleting ozone at the leaf surface.

Surface-assisted ozonolysis not only protects plants from uptake of phytotoxic ozone through stomata, but also acts as a source of volatile carbonyls into the atmosphere, impacting atmospheric chemistry. To our knowledge, our study reports for the first time on detailed measurements of plant surfaceassisted ozonolysis of semi-volatile diterpenoids forming volatile carbonyl products.

\section{Materials and methods}

\subsection{Plant material}

We used the following four tobacco cultivars: Ambalema, secreting only the diterpenoid cis-abienol $\left(\mathrm{C}_{20} \mathrm{H}_{34} \mathrm{O}\right.$, see Fig. 1), BYBA secreting $\alpha$ - and $\beta$-cembratrien-diols (CBTdiols, $\mathrm{C}_{20} \mathrm{H}_{34} \mathrm{O}_{2}$, see Fig. 1), and Basma Drama, secreting all these compounds (Sallaud et al., 2012). The new 3H02 line does not exude diterpenoids at all (see Appendix A).

Seeds of the tobacco cultivars were obtained from the Leibniz Institute of Plant Biochemistry, Department of Cell and Metabolic Biology, Halle. The plants were grown in the green houses of the Institute of Ecology of the University of Innsbruck for 8-10 weeks in standard soil.

Before being used in the experiments the sample plants were allowed to adapt 1-4 weeks in the laboratory, obtaining light from the same true light lamp type as used during the measurements (see Sect. 2.2). 


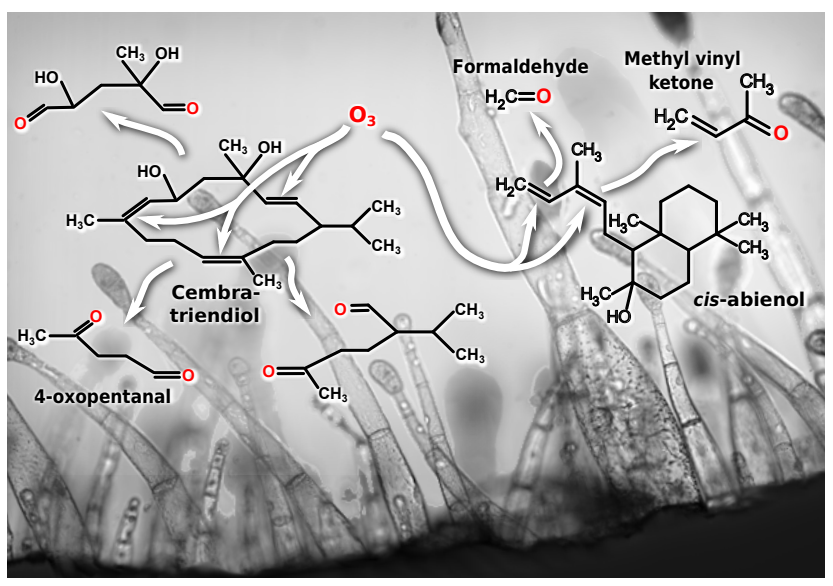

Figure 1. Ozonolysis of diterpenoids exuded by the trichomes of the investigated tobacco plants. The $B Y B A$ variety releases $\alpha$ - and $\beta$ cembratrien-diols $\left(\mathrm{C}_{20} \mathrm{H}_{34} \mathrm{O}_{2}\right)$, the Ambalema variety cis-abienol $\left(\mathrm{C}_{20} \mathrm{H}_{34} \mathrm{O}\right)$; the Basma Drama variety exudes all these compounds. Ozonolysis of the cembratriendiols requires at least two ozonolysis steps to form short-chained, volatile carbonyls, e.g. 4-oxopentanal $\left(\mathrm{C}_{5} \mathrm{H}_{8} \mathrm{O}_{2}\right)$. Ozonolysis of cis-abienol leads to the formation of volatile formaldehyde $(\mathrm{HCHO})$ and methyl vinyl ketone $\left(\mathrm{C}_{4} \mathrm{H}_{6} \mathrm{O}\right)$. The background image shows glandular trichomes on a tobacco leaf.

Plants were installed into the plant enclosure used for ozone fumigation the evening before the actual experiment, so they could adapt to the system and recover from possible stress during installation. The sample plants were well watered and in a good physiological condition and showed no visible signs of damage. At the beginning of the experiments, when no ozone was added, no significant stress signals in form of green leaf volatiles were detected.

In total, combined dark and light ozone fumigation experiments were conducted with five Ambalema, two Basma Drama, one BYBA and three 3H02 samples. Moreover, experiments under solely light conditions were conducted with eight Ambalema, four Basma Drama, four BYBA, and two 3H02 plants. Each sample plant was tested only once.

\subsection{Setup}

In the present ozone experiments we used only inert materials such as Teflon ${ }^{\circledR}$, PEEK ${ }^{\circledR}$ or Duran ${ }^{\circledR}$ glass in order to minimize artificial side-reactions of ozone with unsaturated compounds, present in, e.g. sealing materials like rubber. Moreover, special care was taken to avoid fingerprints, which could result in side reactions of ozone with skin oils (Wisthaler and Weschler, 2010). Ozone loss, estimated from measured ozone concentrations at the inlet and outlet of the empty plant enclosure, was typically less than $5 \%$.

For plant fumigation, synthetic air 5.0 grade was mixed with $\mathrm{CO}_{2} 4.8$ grade (both Messer Austria GmbH, Gumpoldskirchen, Austria). By bubbling the air in distilled water and passing it by a subsequent thermoelectric cooler (TEC) the relative humidity was set. Before entering the plant enclosure, the air was flushed through an ozone generator (UVP, Upland (CA), USA). The enclosure system consisted of a desiccator (Schott Duran ${ }^{\circledR}$ ) of 17.3 L volume, turned upside-down, and two end-matched PTFE ${ }^{\circledR}$ ground plates. A central hole served as feed-through for the plant stem, possible gaps were sealed with Teflon ${ }^{\circledR}$ tape. The (single-sided) leaf area enclosed was typically in the range of $250-850 \mathrm{~cm}^{2}$.

An ozone detector (Model 49i, Thermo Fisher Scientific Inc. Franklin (MA), USA) and an infra-red gas analyser (LI-840A CO $\mathrm{CH}_{2} / \mathrm{H}_{2} \mathrm{O}$ Analyzer, LI-COR ${ }^{\circledR}$ inc., Lincoln (NE), USA) were sampling at $2 \mathrm{~min}$ intervals from either the inlet or outlet of the enclosure. Plant enclosure inlet ozone concentrations were typically kept constant throughout each experiment and were adjusted to obtain realistic ambient ozone concentrations at the enclosure outlet during light conditions (e.g. $\sim 60$ ppbv in Fig. 3). Relative humidity in the plant enclosure ranged from typically $\sim 55 \%$ in dark experiments up to $\sim 95 \%$ in light experiments.

VOC were quantitatively detected at the enclosure outlet by a Selective Reagent Ionization Time-of-Flight Mass Spectrometer (SRI-ToF-MS, see next section) which was switched every 6 min between $\mathrm{H}_{3} \mathrm{O}^{+}$and $\mathrm{NO}^{+}$reagent ion mode.

Sample plants were illuminated by a true light lamp (Dakar, MT/HQI-T/D, Lanzini Illuminazione, Brescia, Italy). Infra-red light was shielded off by a continuously flushed water bath in order to prevent heating of the plant enclosure. Photosynthetically active radiation (PAR) was measured with a sunshine sensor (model BF3, Delta T Devices Ltd, Cambridge, UK) and temperature on the outer plant enclosure surface with K-type thermocouples.

\subsection{SRI-ToF-MS}

The UIBK Advanced SRI-ToF-MS (University of Innsbruck Advanced Selective Reagent Ionization Time-of-Flight Mass Spectrometer, Breitenlechner and Hansel, 2015) combines the high mass resolution of PTR-ToF-MS (Graus et al., 2010) with the capability to separate isomeric compounds having specific functional groups. For this purpose, the SRI-ToFMS makes use of different chemical ionization pathways of a set of fast switchable primary ions (here: $\mathrm{H}_{3} \mathrm{O}^{+}$and $\mathrm{NO}^{+}$). Moreover, the employment of different primary ions could help to differentiate molecules suffering from fragmentation onto the same mass to charge ratio in the standard $\mathrm{H}_{3} \mathrm{O}^{+}$ mode (Karl et al., 2012).

Examples of differentiable isomers are aldehydes and ketones. In the $\mathrm{H}_{3} \mathrm{O}^{+}$reagent ion mode, aldehydes and ketones both exhibit proton transfer and thus, e.g. methyl vinyl ketone (MVK) and methacrolein (MACR) are both detected as $\mathrm{C}_{4} \mathrm{H}_{7} \mathrm{O}^{+}\left(m / z\right.$ 71.050). In $\mathrm{NO}^{+}$reagent ion mode, most aldehydes exhibit hydride ion transfer and ketones clustering reactions, comparable to the ionization mechanisms in 
a SIFT instrument (Španěl et al., 1997). Thus MVK is detected as $\mathrm{C}_{4} \mathrm{H}_{6} \mathrm{O} \cdot \mathrm{NO}^{+}(\mathrm{m} / z 100.040)$, whereas MACR is detected as $\mathrm{C}_{4} \mathrm{H}_{5} \mathrm{O}^{+}(m / z$ 69.034).

In addition to isomeric separation, the high flow through the drift tube (here: $\sim 500 \mathrm{~mL} \mathrm{~min}^{-1}$ compared to 10 $20 \mathrm{~mL} \mathrm{~min}^{-1}$ in a standard instrument) allows for the first time the detection of semi-volatile compounds such as the diterpenoid cis-abienol $\left(\mathrm{C}_{20} \mathrm{H}_{34} \mathrm{O}\right)$.

The SRI-ToF-MS was operated under standard conditions, $60^{\circ} \mathrm{C}$ drift tube temperature, 540 or $350 \mathrm{~V}$ drift voltage and 2.3 mbar drift pressure, corresponding to an $E / N$ of 120 or $78 \mathrm{Td}$ ( $E$ being the electric field strength and $N$ the gas number density; $1 \mathrm{Td}=10^{-17} \mathrm{~V} \mathrm{~cm}^{2}$ ) in $\mathrm{H}_{3} \mathrm{O}^{+}$or $\mathrm{NO}^{+}$reagent ion mode, respectively. The instrument was calibrated approximately once a week by dynamic dilution of VOC using two different gas standards (Apel Riemer Environmental Inc., Broomfield (CO), USA), containing ca. 30 different VOC of different functionality distributed over the mass range of 30-204 amu. Full SRI-ToF-MS mass spectra were recorded up to $m / z 315$ with a $1 \mathrm{~s}$ time resolution. Raw data analysis was performed using the PTR-ToF Data Analyzer v3.36 and v4.17 (Müller et al., 2013).

\section{4 cis-abienol identification}

For the identification of cis-abienol a pure standard was acquired (Toronto Research Chemicals, Toronto, Canada). The powder was dissolved in n-hexane and applied on the surface of a glass container, which was put into the enclosure system and treated like the plant samples. In $\mathrm{H}_{3} \mathrm{O}^{+}$ reagent ion mode, the major cis-abienol derived signal was detected on $m / z 273.258\left(\mathrm{C}_{20} \mathrm{H}_{33}^{+}\right)$; like many other alcohols, cis-abienol is losing $\mathrm{H}_{2} \mathrm{O}$ after the protonation reaction. Minor fragment signals in the range of a few percent were detected at $m / z 191.180\left(\mathrm{C}_{14} \mathrm{H}_{23}^{+}\right), m / z 163.149\left(\mathrm{C}_{12} \mathrm{H}_{19}^{+}\right)$and $m / z 217.196\left(\mathrm{C}_{16} \mathrm{H}_{25}^{+}\right)$, respectively.

In $\mathrm{NO}^{+}$reagent ion mode, the major cis-abienol derived signals were detected at $m / z 272.250\left(\mathrm{C}_{20} \mathrm{H}_{32}^{+}\right)$and $m / z 178.172\left(\mathrm{C}_{13} \mathrm{H}_{22}^{+}\right)$. Minor signals were measured at $m / z 163.149\left(\mathrm{C}_{12} \mathrm{H}_{19}^{+}\right)$and $m / z 134.101\left(\mathrm{C}_{10} \mathrm{H}_{14}^{+}\right)$, respectively.

Ozonolysis of the pure cis-abienol standard yielded the same primary ozonolysis products (see below) as in the case of Ambalema plants.

\subsection{Leaf stripping}

In order to relate the observed ozonolysis carbonyls to plant surface reactions, leaf exudates of untreated tobacco plants were stripped off by dipping leaves (of similar area) of untreated Ambalema, Basma Drama and 3H02 plants into nhexane $\left(\sim 100 \mathrm{~mL}\right.$ for $1000 \mathrm{~cm}^{2}$ leaf area) for $\sim 1 \mathrm{~min}$. The n-hexane - leaf exudate solution was then distributed as evenly as possible onto the inner surface of the empty desiccator serving as plant enclosure. $n$-hexane evaporated quickly and was further reduced by flushing the glass cuvette with pure synthetic air. Afterwards, ozone fumigation experiments were performed similar to the experiments with intact plants.

\subsection{GC-MS analysis}

Non-volatile ozonolysis products and unreacted surface compounds were analysed by GC-MS (see also Supplement). Directly after the ozone fumigation experiments we extracted leaf exudates and low-volatility ozonolysis products from the fresh tobacco leaves (see Sect. 2.5). $1 \mu \mathrm{L}$ portions of the samples were then injected directly into a GC-MS for analysis on a $6890 \mathrm{~N}$ gas chromatograph coupled to a $5973 \mathrm{~N}$ mass spectrometer (Agilent Technologies) according to the procedures described elsewhere (Sallaud et al., 2012).

Tobacco diterpenoids were identified on the basis of their mass spectra, as described in the literature (Enzell et al., 1984).

\subsection{Calculation of leaf gas exchange parameters}

For the calculation of the gas exchange parameters we followed well-established procedures by Caemmerer and Farquhar (1981) and Ball (1987). Transpiration rate $E$, assimilation rate $A$, total ozone flux $F_{\text {tot, } \mathrm{O}_{3}}$ and total water vapour conductance $g_{1, \mathrm{H}_{2} \mathrm{O}}$ were calculated from

$$
\begin{gathered}
E=\frac{u_{\mathrm{e}}}{s} \cdot \frac{w_{\mathrm{o}}-w_{\mathrm{e}}}{1-w_{\mathrm{o}} \times 10^{-3}},\left[\mathrm{mmolm}^{-2} \mathrm{~s}^{-1}\right] \\
A=\frac{u_{\mathrm{e}}}{s} \cdot\left[c_{\mathrm{e}}-\left(\frac{1-w_{\mathrm{e}} \times 10^{-3}}{1-w_{\mathrm{o}} \times 10^{-3}}\right) \cdot c_{\mathrm{o}}\right] \\
\quad\left[\mu \mathrm{mol} \mathrm{m}{ }^{-2} \mathrm{~s}^{-1}\right] \\
F_{\mathrm{tot}, \mathrm{O}_{3}}=\frac{u_{\mathrm{e}}}{s} \cdot\left[o_{\mathrm{e}}-\left(\frac{1-w_{\mathrm{e}} \times 10^{-3}}{1-w_{\mathrm{o}} \times 10^{-3}}\right) \cdot o_{\mathrm{o}}\right], \\
\quad\left[\mathrm{nmol} \mathrm{m}{ }^{-2} \mathrm{~s}^{-1}\right] \\
g_{1, \mathrm{H}_{2} \mathrm{O}}=\frac{10^{3} \cdot E\left(1-\frac{w_{\mathrm{o}}+w_{\mathrm{i}}}{2 \times 10^{3}}\right)}{w_{\mathrm{i}}-w_{\mathrm{o}}},\left[\mathrm{mmol} \mathrm{m}^{-2} \mathrm{~s}^{-1}\right],
\end{gathered}
$$

with $u_{\mathrm{e}}$ the molar flow of air entering the enclosure in $\left[\mathrm{mols}^{-1}\right], s$ the leaf area in $\left[\mathrm{m}^{2}\right], w_{\mathrm{e}} / c_{\mathrm{e}} / o_{\mathrm{e}}$ and $w_{\mathrm{o}} / c_{\mathrm{o}} / o_{\mathrm{o}}$ the mole fraction of water vapour/ $\mathrm{CO}_{2} /$ ozone entering respectively leaving the plant enclosure in $\left[\mathrm{mmol} \mathrm{mol}^{-1}\right]$, $\left[\mu \mathrm{mol} \mathrm{mol}^{-1}\right]$ and $\left[\mathrm{nmol} \mathrm{mol}^{-1}\right.$ ], respectively. $w_{\mathrm{i}}$ is the mole fraction of water vapour inside the leaf in $\left[\mathrm{mmol} \mathrm{mol}^{-1}\right]$ and is typically assumed to be the saturation mole fraction at leaf temperature (Ball, 1987).

For the calculation of the total ozone conductance we applied a ternary diffusion model as has been proposed by Caemmerer and Farquhar (1981). Thereby, pairwise interactions between ozone, water vapour and air are considered (for the sake of simplicity we neglected interactions with $\mathrm{CO}_{2}$ ). Interactions of ozone molecules with water vapour are important only for that portion of ozone, which is entering the 
stomatal pores and not for that lost in reactions at the leaf surface. However, in the latter case the consideration of binary diffusion between ozone and water leads to an overestimation of the total ozone conductance in the range of $<1 \%$.

Total ozone conductance $g_{1, \mathrm{O}_{3}}$ is then defined by

$g_{1, \mathrm{O}_{3}}=\frac{-10^{3} \cdot F_{\mathrm{tot}, \mathrm{O}_{3}}+\left(\frac{o_{\mathrm{a}}+o_{\mathrm{i}}}{2}\right) \cdot E}{o_{\mathrm{a}}-o_{\mathrm{i}}},\left[\mathrm{mmol} \mathrm{m}^{-2} \mathrm{~s}^{-1}\right]$,

with $o_{\mathrm{i}}$ and $o_{\mathrm{a}}$ the mole fractions of ozone inside the leaf (at the leaf surface for reactive leaf surfaces) and in the surrounding air, respectively. $o_{\mathrm{a}}$ equals the ozone mole fraction $o_{\mathrm{o}}$ measured at the outlet of the plant enclosure. Typically, we consider $o_{\mathrm{i}} \approx 0$ (Laisk et al., 1989) and therefore Eq. (5) simplifies further to

$g_{1, \mathrm{O}_{3}}=\frac{-10^{3} \cdot F_{\mathrm{tot}, \mathrm{O}_{3}}+\frac{o_{\mathrm{a}}}{2} \cdot E}{o_{\mathrm{a}}}$.

\subsection{Quantification of the ozone depletion capability of individual plants}

In our fumigation experiments the ozone concentrations in the plant enclosure varied between the different experiments and within experiments switching from light to dark conditions. In order to compare the ozone depletion capability (i.e. surface plus stomatal sinks) of different plants or of the same plant under dark and light conditions, it is therefore important to use a concentration independent measure. As for a given ozone conductance the ozone flux increases with the ambient ozone concentration (cf. Eqs. 3 and 6), we follow others (see e.g. Wohlfahrt et al., 2009) and use the ozone conductance values instead. In experiments with plants having an ozone reactive surface, the total ozone conductance $g_{1, \mathrm{O}_{3}}$ (Eq. 6) comprises boundary layer conductance, stomatal conductance, and cuticular conductance. Stomatal and boundary layer ozone conductances can be calculated from those of water vapour by correcting for the different diffusivities of the two gases. The boundary layer water vapour conductance could be determined by measuring temperature and evaporation rate from leaf models made of chromatography paper (see Ball, 1987). However, in our experiments this was not really practical for all sample plants which were all complexly and differently shaped. Consequently, also the stomatal water vapour and ozone conductances could not be inferred from the calculated total water vapour conductance (Eq. 4).

As we show in the Supplement, even if stomatal and boundary layer ozone conductances are known, for semireactive leaf surfaces the calculation of stomatal and nonstomatal parts of the total ozone flux is not feasible.

For these reasons we report here only total ozone conductance values (Eq. 6), normalized to the single-sided leaf area or to the area of the enclosure covered with leaf exudates in experiments with pure leaf surface compounds (see Sect. 2.5).

\subsection{Statistical analysis}

Data $\left(g_{1, \mathrm{O}_{3}}, A, g_{1, \mathrm{H}_{2} \mathrm{O}}\right)$ were tested for statistically significant differences between dark and light experiments (using the same variety) and between different tobacco varieties (in either dark or light experiments), respectively, using the Wilcoxon-Mann-Whitney test in Matlab ${ }^{\circledR}$. Due to the partially small sample size, probabilities $p<0.1$ are reported as marginally significant. Lacking replicates of dark experiments with $B Y B A$ plants, in the statistical analysis this type of experiment was omitted.

\subsection{Fluid dynamic calculations}

In order to visualize the ozone concentration gradients caused by plant ozone uptake, two idealized setups were simulated: a macroscopic plant model in an ambient air flow and a microscopic model for the stomatal gas exchange. The simulations were done using the open-source CFD code OpenFOAM (www.openfoam.com).

In the microscopic model the air flow was neglected and a pure diffusion process was simulated. Stomata were modelled as $100 \mu \mathrm{m}$ long and $40 \mu \mathrm{m}$ wide eye-shaped openings recessed $20 \mu \mathrm{m}$ deep into the leaf surface. The simulation domain with 500000 cells covered an area of $300 \mu \mathrm{m}$ square around the stoma and extended $2 \mathrm{~mm}$ from the leaf surface into the surrounding gas. A single stoma with cyclic boundaries was used to represent a whole leaf with stomata spread repeatedly over its surface. The ozone-reactive bottom of the stomata was modelled as $100 \%$ efficient sink (Laisk et al., 1989 ) with a constant ozone concentration of zero, while the side walls of the stomata were assumed not to absorb ozone and set to zero gradient. The top of the measurement domain acting as ozone inlet from the surrounding was set to one. The leaf surface around the stomata was set to zero gradient or to a fixed concentration of zero, representing two idealized plant types with either non-reactive or reactive leaf surface. "scalarTransportFoam" was run on this grid with a uniform zero velocity field until a steady state was reached.

For the macroscopic model (see Supplement) a laminar flow around the plant was simulated using the steady-state Reynolds averaged Navier-Stokes solver "simpleFoam", the transport of ozone in the resulting flow velocity field was studied using the "scalarTransportFoam" solver. The simulated gas volume consisted of a cube with $20 \mathrm{~cm}$ edge length with the shape of an exemplary tobacco plant cut out of its volume (see Fig. S3). The resulting simulation domain was divided into a hexahedron-dominant grid of 3.7 million cells with the finest granularity around the stomata and the leaf surfaces with the OpenFOAM tool "snappyHexMesh". The domain was divided into eight subdomains for parallel computation. Stomata were represented by small patches spread equally over the leaf surfaces, covering $10 \%$ of the total leaf area. The boundary conditions for the gas flow simulation consisted of an inlet with $2 \mathrm{~mm} \mathrm{~s}^{-1}$ velocity entering on one 
face of the cube and a constant pressure boundary condition outlet on the opposite face. The gas velocity on the plant surface was set to zero. Initial conditions for the flow simulation were calculated with "potentialFoam" to speed up convergence of the "simpleFoam" solver. The simulation was run until the flow velocity field reached a steady state. For the diffusion calculations a relative initial concentration of ozone was set to one at the inlet and to zero on the stomata patches. Like in the microscopic model calculations, the leaf surface was either a zero concentration gradient boundary (for an idealized 3H02 plant type) or a fixed concentration value of zero (for an idealized Ambalema plant type). In the previously calculated velocity field the ozone transport was simulated until a steady state was reached, too.

\section{Results and discussion}

\subsection{Expected ozonolysis products of cis-abienol and cembratrien-diols}

Apart from the $3 \mathrm{H} 02$ variety, the investigated tobacco varieties secrete different unsaturated diterpenoids (see Sect. 2.1). According to the Criegee mechanism (Criegee, 1975), ozone attacks the carbon double bonds of alkenes forming primary carboyls and so-called Criegee Intermediates (see Supplement). Criegee Intermediates are, however, expected to be too short-lived to be detected directly by the instruments used in our experiments (see Supplement). We were therefore interested primarily in the stable, volatile ozonolysis carbonyls, which could be detected in real-time by our SRI-ToF-MS.

For the semi-volatile diterpenoid cis-abienol with two exocyclic double bonds, exuded by the Ambalema and Basma Drama varieties, we expected the formation of formaldehyde $(\mathrm{HCHO})$ and methyl vinyl ketone $\left(\mathrm{MVK}, \mathrm{C}_{4} \mathrm{H}_{6} \mathrm{O}\right.$, see Fig. 1).

In the case of the ring structured CBTdiols with three endocyclic double bonds, produced by the Basma Drama and $B Y B A$ plants, at least two ozonolysis steps are needed to form volatile carbonyls. The three smallest carbonyl products are shown in Fig. 1, whereby 4-oxopentanal $\left(\mathrm{C}_{5} \mathrm{H}_{8} \mathrm{O}_{2}\right)$ is expected to be the most volatile one (Goldstein and Galbally, 2007).

\subsection{Ozone fumigation experiments with pure leaf surface compounds}

In order to relate a release of carbonyls to surface chemistry only and to exclude stimulated emissions caused, e.g. by the plant ozone defence system, we investigated ozone reactions with pure leaf surface extracts. Leaf surface compounds were extracted with n-hexane and subsequently applied onto the inner surface of an empty plant enclosure and fumigated with ozone (see Sect. 2.5).

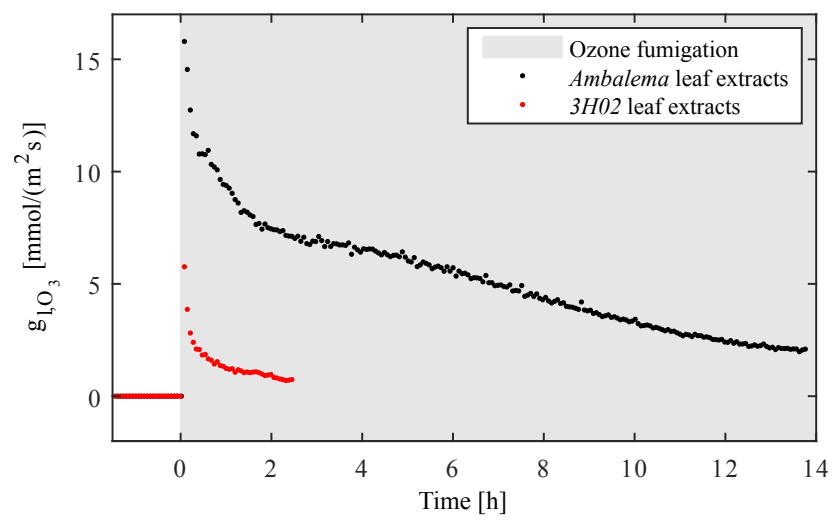

Figure 2. Ozonolysis experiments with pure leaf exudates extracted from non-ozone fumigated, unimpaired plants. The leaf extracts containing the surface compounds were applied to the inner surface of the empty plant enclosure system (see Sect. 2). During ozone fumigation (grey shaded area), the total ozone conductance $g_{1, \mathrm{O}_{3}}$ to the enclosure surface was much higher for Ambalema leaf extracts (containing large amounts of the diterpenoid cis-abienol) than for 3H02 extracts. Moreover, it remained high for many hours.

Ambalema leaf extracts showed a weak signal of cis- abienol (we refer to Sect. 2.4 for the identification of this compound), which disappeared during ozone fumigation while MVK and formaldehyde were prominently observed. These carbonyls were produced by surface-assisted ozonolysis of cis-abienol (see Fig. 1). MVK was detected at $m / z 71.050$ $\left(\mathrm{C}_{4} \mathrm{H}_{7} \mathrm{O}^{+}\right)$and $m / z 100.040\left(\mathrm{C}_{4} \mathrm{H}_{6} \mathrm{O} \cdot \mathrm{NO}^{+}\right)$in the $\mathrm{H}_{3} \mathrm{O}^{+}$ and $\mathrm{NO}^{+}$reagent ion mode of the SRI-ToF-MS, respectively. Formaldehyde was detected only using $\mathrm{H}_{3} \mathrm{O}^{+}$as reagent ion at $m / z 31.018\left(\mathrm{CH}_{3} \mathrm{O}^{+}\right)$, taking into account the humidity dependent sensitivity (Hansel et al., 1997). In the $\mathrm{NO}^{+}$ reagent ion mode formaldehyde cannot be ionized (Španěl et al., 1997), consequently we detected no signal.

In the ozone fumigation experiments using Basma Drama leaf extracts, besides MVK and formaldehyde as ozonolysis products of cis-abienol, also the most volatile CBTdiol ozonolysis product - 4-oxopentanal - was detected in the gas phase by SRI-ToF-MS. 4-oxopentanal was detected at $m / z 101.060\left(\mathrm{C}_{5} \mathrm{H}_{9} \mathrm{O}_{2}^{+}\right)$in $\mathrm{H}_{3} \mathrm{O}^{+}$and $m / z 99.045\left(\mathrm{C}_{5} \mathrm{H}_{7} \mathrm{O}_{2}^{+}\right)$ in $\mathrm{NO}^{+}$reagent ion mode, respectively.

No significant amount of volatile carbonyls was observed from ozonolysis of $3 \mathrm{H} 02$ leaf extracts. Consistently, the total ozone conductance was far less than in experiments with extracts from diterpenoid-exuding tobacco varieties (see Fig. 2). This is in line with the results from the corresponding experiments with intact plants (see below). The ozone depletion efficiency of the $3 \mathrm{H} 02$ exudates was decreasing fast, while the presence of $c i s$-abienol in Ambalema leaf exudates kept the ozone conductance at elevated levels for many hours (cf. Fig. 2). 


\subsection{Ozone fumigation experiments with diterpenoid exuding tobacco varieties}

Also in experiments with intact plants we observed a prompt release of volatile carbonyls as soon as the tobacco leaves were fumigated with ozone. The Ambalema and Basma Drama varieties released MVK and formaldehyde. In addition, we detected sclaral, a non-volatile compound, in surface extracts obtained from ozone fumigated plants of the same varieties (see Sect. 2 and Supplement). Sclaral is an isomerization product of the $\mathrm{C}_{16}$ carbonyl formed in cis-abienol ozonolysis (cf. Fig. 1). All these compounds can therefore be attributed again to surface-assisted ozonolysis of cis-abienol (see Fig. 1).

In experiments using Basma Drama and BYBA plants we detected the CBTdiol ozonolysis product 4-oxopentanal, similar to the ozone fumigation experiments with leaf surface extracts (see previous section).

Figure 3 shows a typical result of an ozonolysis experiment using Ambalema plants. Immediately after starting the ozone fumigation, the cis-abienol signal decreased, while initial bursts of MVK and formaldehyde were detected. These initial bursts can be attributed to surface ozonolysis of cisabienol deposited on all surfaces (i.e. surfaces of the whole plant, the enclosure and the enclosure outlet tubing) during plant acclimatization under ozone free conditions lasting $>12 \mathrm{~h}$ (see Sect. 3.6 and Supplement).

In plant experiments using diterpenoid exuding tobacco varieties, the carbonyl emission and consequently the total ozone conductance and flux (under constant light) eventually reached a steady state, when the diterpenoid production by the trichomes (leading to a permanent deposition of those onto the plant surface) and plant surface reactions were in equilibrium (cf. Fig. 3). This is in contrast to experiments with pure leaf surface compounds, in which the diterpenoids were slowly consumed as ozone fumigation progressed (see Sect. 3.2).

Simulating diurnal ozone variations over 2 days in experiments with Ambalema and Basma Drama plants, we could show that the reactive layer at the plant surface is a large pool and not quickly consumed (see Supplement and Fig. S2). We therefore assume that the diterpenoids released are likely to represent a long-term ozone protection for these varieties.

\subsection{Variety-specific ozone depletion during dark and light phases}

In further experiments we investigated the ozone depletion by different tobacco varieties under dark and light conditions.

In dark experiments, when stomatal pores are almost closed, the Ambalema variety showed the highest total ozone conductance under steady-state conditions (cf. Fig. 4, top panel). This is a direct indication for the high ozone depletion capacity of the surface of this variety.

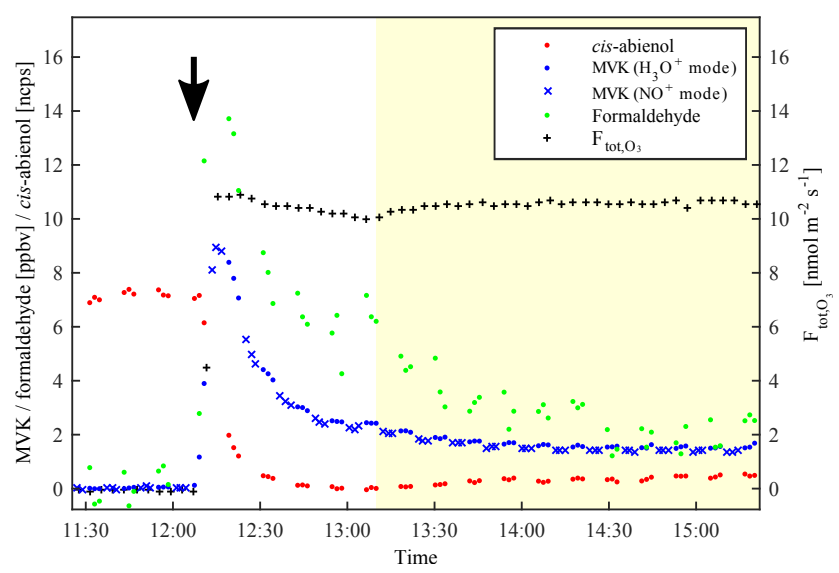

Figure 3. Temporal evolution of selected VOC in an ozonolysis experiment with an Ambalema plant and corresponding total ozone deposition flux $F_{\text {tot, } \mathrm{O}_{3}}$. The yellow shaded area denotes time ranges, in which the sample plant was illuminated. Starting the fumigation with $\sim 60 \mathrm{ppbv}$ ozone (indicated by the black arrow) the $c i s$-abienol signal decreased quickly. At the same time, the carbonyl products of cis-abienol ozonolysis, formaldehyde and MVK (measured in $\mathrm{H}_{3} \mathrm{O}^{+}$respectively $\mathrm{NO}^{+}$reagent ion mode of the SRI-ToF-MS), started to rise. The large scattering of the formaldehyde signal derives from the strongly reduced sensitivity of the SRI-ToF-MS under high humidity conditions towards this compound. Two hours after the start of the ozone fumigation an equilibrium between actual diterpenoid production and loss due to surface reactions was established, resulting in stable signals of the oxygenated VOC.

Due to the lack of reactive diterpenoids on the leaf surface of $3 \mathrm{H} 02$ plants, the surface ozone sink plays a minor role for this tobacco line. However, we cannot totally exclude the presence of other unsaturated compounds at the surface of this variety.

The low surface reactivity of the Basma Drama and $B Y B A$ varieties correlates with the lower amount of detected ozonolysis carbonyls compared to that of the Ambalema variety in dark conditions. This might be related to a lower diterpenoid surface coverage of these two varieties and the expected lower reactivity of the CBTdiols having endocyclic double bonds (Atkinson and Arey, 2003).

The Ambalema variety also shows a higher $g_{1, \mathrm{H}_{2} \mathrm{O}}$ and dark respiration than the other varieties (cf. Fig. 4, middle and bottom panels). $g_{1, \mathrm{H}_{2} \mathrm{O}}$ linearly correlates with the stomatal water vapour conductance and therefore also with the stomatal ozone conductance. However, higher stomatal conductance during dark conditions cannot explain the large differences in $g_{1, \mathrm{O}_{3}}$ between the plant types. While $g_{1, \mathrm{H}_{2} \mathrm{O}}$ of the Ambalema variety in dark conditions is about twice as high as that of the $3 \mathrm{H} 02$ variety, the corresponding $g_{1, \mathrm{O}_{3}}$ is four times as high.

When switching from dark to light conditions we assume cuticular conductance not to change significantly and thus an increase in the calculated $g_{1, O_{3}}$ is attributable mainly to an increasing stomatal ozone conductance. In the case of Ambalema, switching the light on increased the total conduc- 

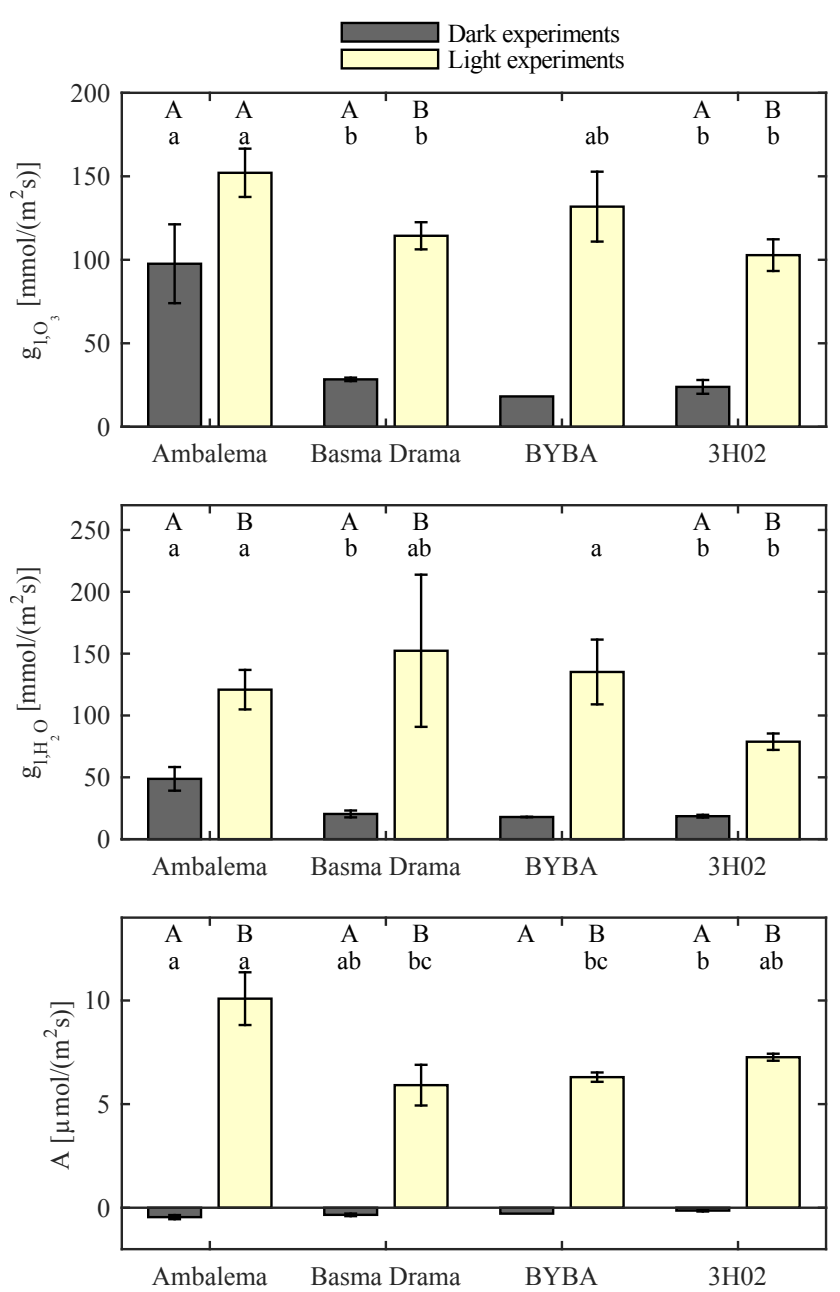

Figure 4. Total ozone conductance $g_{1, \mathrm{O}_{3}}$ (top), total water vapour conductance $g_{1, \mathrm{H}_{2} \mathrm{O}}$ (middle) and assimilation rates $A$ (bottom) of different tobacco varieties during dark and light conditions. Error bars denote the standard error of 5 (13), 2 (6), 1 (5) and 3 (5) replicates of Ambalema, Basma Drama, BYBA respectively 3H02 in dark (light) experiments. Different capital letters denote significant different means in light and dark experiments of the same plant type and lower case letters significant different means of different plant types in either dark or light experiments, respectively (WilcoxonMann-Whitney test, $p<0.1$, see Sect. 2.9. Lacking replicates in the statistical analysis dark experiments using BYBA plants were omitted). Under dark conditions stomatal ozone conductance is generally low and consequently surface reactions are the major ozone sink. The surface sink is high for the Ambalema tobacco line, which exudes cis-abienol and lower for the other lines, exuding less reactive or no diterpenoids.

tance by $\sim 55 \%$ (see Fig. 4 , top panel). In contrast, in the $3 \mathrm{H} 02$ case, switching on the light triggered a substantial increase in the total ozone conductance by $\sim 340 \%$ (cf. Fig. 4, top panel).

During light conditions the total ozone conductances of the different tobacco varieties were in a comparable range; slightly higher values were observed for the diterpenoid exuding lines Ambalema, Basma Drama, and BYBA.

Statistical analysis confirmed the observed tendencies of the total ozone conductance: only for the Ambalema variety was $g_{1, \mathrm{O}_{3}}$ under light conditions not significantly different from the values measured under dark conditions $(p>0.1)$. Conversely, $g_{1, \mathrm{O}_{3}}$ calculated for the Ambalema variety was significantly higher than that of the other tobacco lines under dark conditions ( $p<0.1$, see Fig. 4, top panel).

\subsection{Volatile carbonyl yields from surface ozonolysis}

In the ozone fumigation experiments the yield of volatile ozonolysis products was generally in the low percentage range, e.g. for Ambalema plants $\sim 7 \%$ under dark and $\sim 5 \%$ under light conditions considering the major volatile ozonolysis products MVK and formaldehyde quantified by SRITOF-MS. The slight change from $\sim 7$ to $\sim 5 \%$ when switching from dark to light conditions can be explained by the effect of the open stomata. Open stomata offer an alternative sink for ozone and for volatile carbonyls produced in surface assisted reactions (Karl et al., 2010; Niinemets et al., 2014). The reason why only a small percentage of the consumed ozone is detected as volatile products indicates that most of the ozonolysis products are not volatile enough to leave the plant surface (cf. Fig. 1 and Supplement). The fate of the Criegee Intermediates in surface ozonolysis is discussed in detail in the Supplement.

\subsection{Separation of ozone surface and gas phase reactions}

In order to qualify the measured total ozone fluxes for the calculation of $g_{1, \mathrm{O}_{3}}$ values, we had to take into account the possibility of homogeneous gas phase ozonolysis of the semivolatile diterpenoids exuded by the tobacco varieties.

To assess the significance of gas phase ozonolysis to our results, we connected the plant enclosure containing a diterpenoid emitting tobacco plant with a second empty enclosure downstream and added ozone only to the second enclosure. Only negligible carbonyl signals were observed once the initial burst from deposited diterpenoids faded away (see Supplement and Fig. S1). This result indicates that with our setup gas-phase reactions of the diterpenoids were not significant.

This observation can be explained theoretically, too. The air in our enclosure system was exchanged every $\sim 5 \mathrm{~min}$. Therefore, only extremely fast gas phase ozone-alkene reactions have to be considered. For an ozone concentration of 100 ppbv, a reaction rate of $1.35 \times 10^{-15} \mathrm{~cm}^{3} \mathrm{~s}^{-1}$ results in an alkene ozonolysis lifetime of $5 \mathrm{~min}$. Such fast ozonolysis rates have only been measured for a few very reactive sesquiterpenes (Atkinson and Arey, 2003). We found no reaction rates of cis-abienol and CBTdiols with ozone in the literature to exclude the possibility of a gas phase contribution to total ozone loss in our experiments a priori. Nonethe- 
less, taking into account the estimated vapour pressures of cis-abienol $\left(\sim 10^{-9}\right.$ bar) and CBTdiol $\left(\sim 10^{-12}\right.$ bar) (Goldstein and Galbally, 2007) we can state that the bulk of the exuded diterpenoids stayed at the leaf surface and that other surfaces (e.g. the inner surface of the plant enclosure and the tubing system) were very slowly covered by condensed diterpenoids. This is also the explanation for the bursts of volatile ozonolysis products at the beginning of every ozone fumigation (see e.g. Fig. 3). We therefore assume that gas phase reactions are unlikely to have played a major role in our experiments.

\subsection{Fluid dynamic model calculations}

Microscopic fluid dynamic model calculations (see Materials and methods) revealed the principles responsible for the strong variety-dependent partitioning between stomatal and non-stomatal ozone loss (see Sect. 3.4). The mixed convective and diffusive ozone transport from the surrounding atmosphere to the plant surface and into the stomata was simulated for two idealized plant types under light conditions when the leaf stomata are open. The stomatal pores were exemplarily modelled as small patches uniformly spread over the entire leaf surface. For one model plant we assumed stomatal ozone uptake only, corresponding to an idealized $3 \mathrm{H} 02$ variety plant lacking any reactive surface compounds. The second model plant was representing an idealized Ambalema variety. The surface acted as a perfect ozone sink with every ozone molecule reaching it being lost, either on the leaf surface or through the stomata.

Figure $5 \mathrm{a}$ and $\mathrm{b}$ show the resistance schemes used to describe the ozone flux to the leaves in the two scenarios, which were the basis for our simulations. Ambient ozone has to overcome the boundary layer resistance $R_{\mathrm{b}}$ and the stomatal resistance $R_{\mathrm{S}}$ before being destroyed in the stomatal cavity (for the sake of simplicity we neglected here the mesophyll resistance, which comprises diffusion through inner air spaces and dissolution of the gas in the cell wall water, followed by losses in the aqueous phase, penetration of plasmalemma or chemical reactions in the cell, cf. Neubert et al., 1993). In the case of a non-reactive leaf surface, ozone depletion within the stomata is the sole ozone sink (see Fig. 5a).

In the case of an ozone-reactive leaf surface, an additional surface chemical resistance $R_{\mathrm{sc}}$ has to be introduced, which is parallel to the stomatal resistance (see Fig. $5 \mathrm{~b}$ ). $R_{\mathrm{sc}}$ inversely correlates with the reactive uptake coefficient of ozone at the leaf surface. In the case of the model plant having a non-reactive surface, $R_{\mathrm{sc}}$ is very large $\left(R_{\mathrm{Sc}} \rightarrow \infty\right)$ and ozone flux to the leaf surface can be omitted. Conversely, $R_{\mathrm{sc}}$ is small for reactive surfaces.

The porous leaf surface architecture has special relevance for the gas uptake of plants. For gases having a negligible leaf surface sink (or source) - e.g. $\mathrm{CO}_{2}$ - steep concentration gradients parallel and perpendicular to the surface develop in close proximity to the stomata. These gradients enhance the gas transport in the diffusive leaf boundary layer towards the pores. This effect is extensively described in the literature as the "paradox of pores" (see, e.g. Monson and Baldocchi, 2014). It enables plants to effectively harvest $\mathrm{CO}_{2}$ for photosynthesis, but in the same manner also "funnels" phytotoxic ozone through the stomata into the plant leaves (see Fig. 5c).

In the case of an ozone-reactive leaf surface, $R_{\mathrm{sc}}$ is small compared to $R_{\mathrm{S}}$ and only surface-parallel ozone concentration isosurfaces develop (black lines in Fig. 5d). Concentration gradients (white lines) close to the stomata are exclusively perpendicular to the surface. Consequently, the ozone transport in the diffusive leaf boundary layer is equally distributed over the whole leaf surface and the ozone concentration in this layer is strongly reduced (see Fig. 5d). Similarly, also macroscopic model calculations show that this effect broadens the space of reduced ozone concentrations surrounding a plant with opened stomata (see Supplement and Fig. S3).

The surface-parallel concentration isosurfaces are the reason why we can use the same reference concentration $c_{\mathrm{b}, \mathrm{r}}$ for both the stomatal and the surface chemical resistance, (cf. Fig. 5b). However, this approach does only hold if the leaf surface is a complete ozone sink (see Supplement and Fig. S5).

The different ozone concentration patterns in the two modelled scenarios have important implications for the stomatal ozone uptake. Typically, the stomatal conductance of ozone $g_{\mathrm{s}, \mathrm{O}_{3}}$ is estimated from that of water $g_{\mathrm{s}, \mathrm{H}_{2} \mathrm{O}}$, by correcting for the different diffusivity of the two gases (see e.g. Ball, 1987; Neubert et al., 1993). The stomatal ozone flux $F_{\mathrm{s}, \mathrm{O}_{3}}$ can then be calculated with the following formula:

$F_{\mathrm{s}, \mathrm{O}_{3}}=g_{\mathrm{s}, \mathrm{O}_{3}} \cdot\left(c_{\mathrm{i}, \mathrm{O}_{3}}-c_{\mathrm{b}, \mathrm{O}_{3}}\right)$,

with $c_{\mathrm{i}, \mathrm{O}_{3}}$ being the ozone concentration in the leaf intercellular space and $c_{\mathrm{b}, \mathrm{O}_{3}}$ the ozone concentration in the leaf boundary layer. For high ambient ozone concentrations $c_{\mathrm{i}, \mathrm{O}_{3}}$ was found to be positive (Moldau and Bichele, 2002; Loreto and Fares, 2007), but typically it is assumed to be close to zero (Laisk et al., 1989). Therefore, Eq. (7) simplifies to

$F_{\mathrm{s}, \mathrm{O}_{3}}=-g_{\mathrm{s}, \mathrm{O}_{3}} \cdot c_{\mathrm{b}, \mathrm{O}_{3}}$.

If now surface reactions drastically reduce $c_{\mathrm{b}, \mathrm{O}_{3}}$ (cf. Fig. 5b and d), the effective stomatal ozone flux (see Supplement) and with that the effective ozone dose are also reduced, which eventually determine the phytotoxic effects of ozone to plants (Massman, 2004). At this point, it is important to note that the uptake of non surface-reactive gases such as $\mathrm{CO}_{2}$ is not affected by the altered ozone gradients.

Thus, whenever surface loss plays a role, both surface and stomatal ozone uptake by plants have to be considered together. Previous studies might therefore have overestimated stomatal ozone uptake (e.g. Kurpius and Goldstein, 2003; Cieslik, 2004; Goldstein et al., 2004; Fares et al., 2012). Hence, their reported stomatal ozone flux values should be considered as upper limits. 
(a)

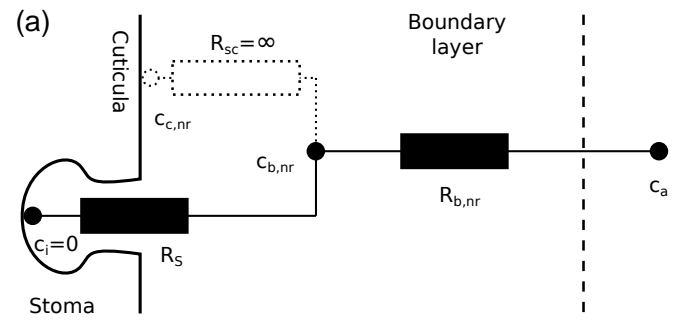

(c)

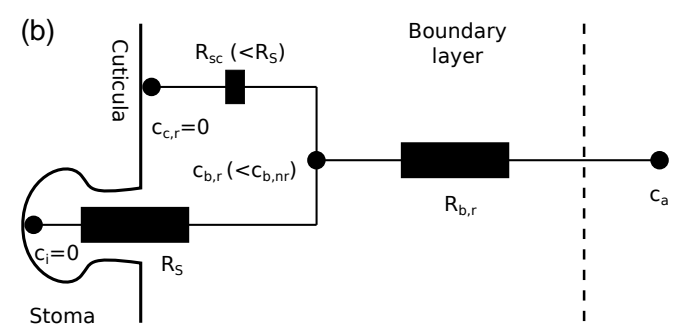

(d)
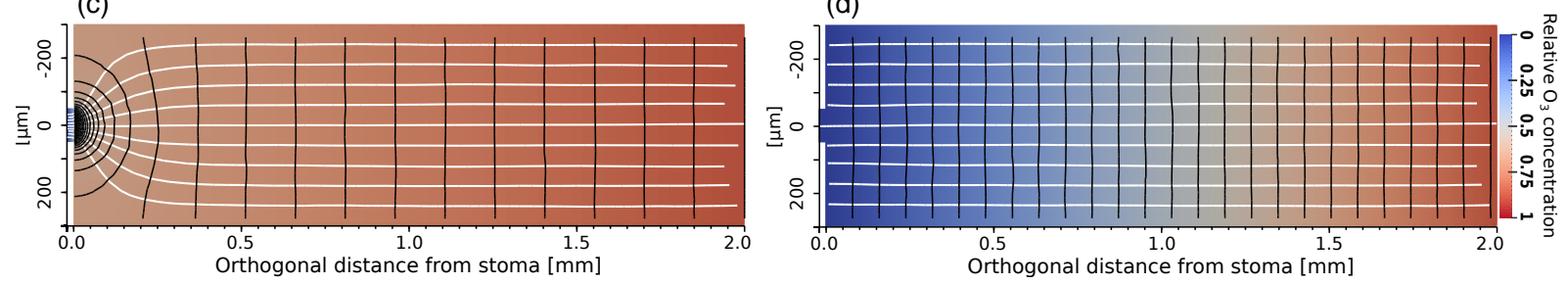

Figure 5. Fluid dynamic calculations of ozone uptake by stomata and leave surface. (a and $\mathbf{b})$ show the resistance schemes for ozone uptake of leaves with non-reactive (nr) and reactive (r) surfaces. $c_{\mathrm{i}}, c_{\mathrm{c}}, c_{\mathrm{b}}$, and $c_{\mathrm{a}}$ denote ozone concentrations in the stomatal cavity, at the leaf surface, in the boundary layer and in ambient air, respectively. $R_{\mathrm{S}}$ and $R_{\mathrm{b}}$ denote the stomatal and boundary layer resistances. The surface chemical resistance $R_{\mathrm{Sc}}$ is infinite $\left(R_{\mathrm{Sc}}=\infty\right)$ on a non-reactive surface. Fluid dynamic calculations reveal ozone concentration gradients (white lines indicate their orientation) evolving parallel and perpendicular to the leaf surface around the stoma (located at the coordinate $(0,0)$ ) in this case $(\mathbf{c})$. If the leaf surface is covered with ozone-reactive substances, the parallel fraction of the ozone gradients vanishes, resulting in isosurfaces of ozone concentration (black lines) parallel to the leaf surface and stronger ozone depletion in the leaf boundary layer (d).

In future studies investigating the ozone depositions to vegetation, it might be worth to analyse also the surface composition of the plants. If the surfaces are covered with substantial amounts of unsaturated organic compounds, surface loss has to be considered right from the beginning in order not to overestimate stomatal ozone uptake. Due to the fact that surface reactions reduce ozone concentrations in the leaf boundary layer, it is not correct to calculate stomatal ozone loss applying the resistance scheme shown in Fig. 5a and to eventually define the surface loss of ozone as that portion of the total loss which is not explainable by gas phase reactions and stomatal uptake.

For real plants the altered ozone gradient profile shown in Fig. 5d is less pronounced depending on stomata depth, which reduces the total stomatal uptake, and reactive surface compounds, which show smaller surface reaction rates than assumed for the idealized $100 \%$ efficient ozone depleting surface (see Supplement). In the case of such semireactive leaf surfaces a more sophisticated resistance scheme has to be used, which strongly complicates the calculation of stomatal and non-stomatal ozone fluxes (see Supplement and Fig. S5). Nonetheless, the simulations explain the experimentally observed behaviour of different tobacco plants very well.

\subsection{Atmospheric implications}

Over the last decade, several studies have shown discrepancies between measured and expected ozone deposition fluxes. Large downward ozone fluxes (Kurpius and Gold- stein, 2003; Goldstein et al., 2004; Fares et al., 2010) and high levels of oxidized VOC (Holzinger et al., 2005) have been taken as evidence for "unconventional in-canopy chemistry" in a Ponderosa pine plantation, the Blodgett forest site. Measured ozone deposition fluxes could not be explained by modelled stomatal and known non-stomatal sinks, such as reactions with measured VOC in the gas phase (Wolfe et al., $2011 a, b)$. The same observation was made by Rannik et al. (2012) in a Scots pine dominated field site in Hyytiälä. All these studies assume the presence of yet unmeasured highly reactive semi- or low-volatile compounds, which have a similar temperature-dependent emission pattern as mono- and sesquiterpenes.

Wolfe et al. (2011b) assumed that the unmeasured reactive compounds might be unsaturated, cyclic terpenoids. Due to their low vapour pressure, the measurement of semi- or low-volatile compounds represents a challenge, since these substances strongly partition into the condensed phase and are therefore easily lost in the inlet systems of most current VOC instrumentation. However, Bouvier-Brown et al. (2007, 2009) were able to identify several different sesquiterpenes in ambient air and in branch enclosure experiments at the Blodgett forest site.

A large number of compounds with diterpenoid backbones were recently observed for the first time in a different Ponderosa pine forest site during the BEACHON-RoMBAS campaign 2011 (Chan et al., 2015). These unsaturated diterpenoids contain the same backbone as abietic acid, a primary component of resin acids. The observed temporal variations 
in concentrations were similar to those of sesquiterpernoids, suggesting they are directly emitted from the local vegetation.

Most recently, Palm et al. (2015) have shown that semiand intermediate volatility organic compounds measured for the first time at the same site with a novel thermal desorption electron impact mass spectrometer (TD-EIMS) could likely close the gap between observed and expected secondary aerosol growth, estimated from gas-phase concentrations of the most abundant measured VOC (mono- and sesquiterpenes, toluene/p-cymene, isoprene). We therefore speculate that the high ozone deposition fluxes in such forest sites could be a result of not only gas-phase reactions, but to a certain extent also of ozone reactions with semi-volatiles emitted or redeposited onto the vegetation surfaces.

Possible sources of the measured and unmeasured higher terpenoids are - among others - constitutive plant emissions or resins, which are known to contain high amounts of sesqui-, di- and triterpenoids (Dell and McComb, 1979; Langenheim, 2003). Resins can be released during mechanical stress, e.g. in the event of hail storms (Bamberger et al., 2011) and could eventually evaporate depending on their vapour pressure (and therefore ambient temperature).

Di- and triterpenoids are also known constituents of surface waxes (Estell et al., 1994a, b; Altimir et al., 2008; Thimmappa et al., 2014). Moreover, it is estimated that about $30 \%$ of vascular plants have glandular trichomes, which often exude higher terpenoid compounds, too (Wagner et al., 2004).

Clearly, additional experiments are needed to better quantify the amount of semi-volatiles deposited onto vegetation surfaces and their impact on atmospheric chemistry.

\section{Conclusions}

Our results reveal for the first time a powerful ozone protection mechanism of plants having an ozone reactive leaf surface. This opportunistic defence mechanism, which is a beneficial side effect of semi-volatile terpenoids emitted onto the leaf surface, takes place before the phytotoxic gas enters the stomata. Plants emitting unsaturated semi-volatile compounds could have an advantageous effect for neighbouring plants as well: either directly by reducing overall ozone concentrations (see Supplement) or indirectly through the deposition of the semi-volatile compounds onto unprotected neighbouring leaves (Schmid et al., 1992; Himanen et al., 2010; Chan et al., 2015).
Reactive surface compounds might also contribute to the varying ozone sensitivity of different conifer species (Schnitzler et al., 1999; Landolt et al., 2000) when exposed to the same cumulative ozone concentrations under light conditions. We anticipate therefore that surface ozonolysis plays an important role for the ozone tolerance of certain conifer species, too.

Our findings have relevance not only for plants, but also for additional ozone-initiated processes that occur in the indoor and outdoor environment. Semi-volatile, unsaturated organic species are common on various surfaces including soil with plant litter (Weiss, 2000; Isidorov et al., 2003; Ormeño et al., 2009), aerosols (Rogge et al., 1993; D'Anna et al., 2009; Baduel et al., 2011), man-made structures (Wisthaler et al., 2005; Weschler et al., 2007; Shi and Zhao, 2015), and even human skin (Wisthaler and Weschler, 2010). These are potential ozone sinks and sources of oxygenated VOC in ozone-rich environments, as has been shown previously (see e.g. Wisthaler et al., 2005; Weschler et al., 2007; D'Anna et al., 2009; Wisthaler and Weschler, 2010; Baduel et al., 2011). We speculate that some of the ozonolysis-derived products may play important roles in atmospheric processes, influencing the budgets of $\mathrm{OH}$ radicals and ozone. Conversely, in our experiments we had no indication that surface ozonolysis itself releases detectable amounts of $\mathrm{OH}$ radicals into the gas phase (see Supplement). In order to assess the global impact of surface-assisted ozonolysis on atmospheric chemistry a more complete knowledge about the nature of reactive, semi- and low-volatile compounds at plant surfaces as well as the mechanisms triggering their release (e.g. constitutive vs. biotic and mechanical stress induced emission) is needed. 
Appendix A: Generation of the $3 \mathrm{HO2}$ variety a Nicotiana tabacum line without diterpenoids

The Ambalema variety which produces only cis-abienol and the Colorado variety which produces only CBTdiols (Sallaud et al., 2012) were crossed to produce hybrid F1 plants which produce both diterpenoids. Because the genetic loci responsible for the absence of CBTdiols and the absence of cisabienol are distinct and unlinked, recombinant plants which produce neither diterpenoids could be recovered by analysing the leaf surface extracts by GC-MS in the selfed progeny of the F1 plants. One of these plants was selected, propagated over two generations by single seed descent and named line $3 \mathrm{H} 02$. 


\section{The Supplement related to this article is available online at doi:10.5194/acp-16-277-2016-supplement.}

Acknowledgements. The authors would like to thank Francesco Loreto who initiated the tobacco experiments, Jörg-Peter (Jogi) Schnitzler for fruitful discussions and the gardeners of the Innsbruck University Botanic Gardens who grew the sample plants. W. Jud would like to thank Sheldon L. Cooper for helpful comments.

This project was financially supported by the European Science Foundation in the frame of the EuroVol MOMEVIP project and by the Austrian Fonds zur Förderung der wissenschaftlichen Forschung, project number I655-B16.

Edited by: D. Farmer

\section{References}

Agathokleous, E., Saitanis, C. J., and Papatheohari, Y.: Evaluation of Di-1-p-Menthene as Antiozonant on Bel-W3 Tobacco Plants, as Compared with Ethylenediurea, Water Air Soil Poll., 225, 2139, doi:10.1007/s11270-014-2139-y, 2014.

Altimir, N., Vesala, T., Aalto, T., Bäck, J., and Hari, P.: Stomatalscale modelling of the competition between ozone sinks at the air-leaf interface, Tellus B, 60, 381-391, doi:10.1111/j.16000889.2008.00344.x, 2008.

Ashmore, M. R.: Assessing the future global impacts of ozone on vegetation, Plant Cell Environ., 28, 949-964, doi:10.1111/j.1365-3040.2005.01341.x, 2005.

Atkinson, R. and Arey, J.: Atmospheric degradation of volatile organic compounds, Chem. Rev., 103, 4605-4638, doi:10.1021/cr0206420, 2003.

Baduel, C., Monge, M. E., Voisin, D., Jaffrezo, J.-L., George, C., Haddad, I. E., Marchand, N., and D'Anna, B.: Oxidation of atmospheric humic like substances by ozone: a kinetic and structural analysis approach, Environ. Sci. Technol., 45, 5238-5244, doi:10.1021/es200587z,2011.

Ball, T.: Calculations related to gas exchange, in: Stomatal Function, edited by: Zeiger, E., Farquhar, G. D., and Cowan, I. R., chap. 20, 445-476, Stanford University Press, Stanford, 1987.

Bamberger, I., Hörtnagl, L., Ruuskanen, T. M., Schnitzhofer, R., Müller, M., Graus, M., Karl, T., Wohlfahrt, G., and Hansel, A.: Deposition fluxes of terpenes over grassland, J. Geophys. Res., 116, 1-13, doi:10.1029/2010JD015457, 2011.

Borowiak, K., Zbierska, J., and Drapikowska, M.: Differences in morpho-anatomical structure of ozone-sensitive and ozoneresistant tobacco cultivars, Acta Biol. Hung., 61, 90-100, doi:10.1556/ABiol.61.2010.1.9, 2010.

Bouvier-Brown, N. C., Holzinger, R., Palitzsch, K., and Goldstein, A. H.: Quantifying sesquiterpene and oxygenated terpene emissions from live vegetation using solid-phase microextraction fibers, J. Chromatogr. A, 1161, 113-120, doi:10.1016/j.chroma.2007.05.094, 2007.

Bouvier-Brown, N. C., Goldstein, A. H., Gilman, J. B., Kuster, W. C., and de Gouw, J. A.: In-situ ambient quantification of monoterpenes, sesquiterpenes, and related oxygenated compounds during BEARPEX 2007: implications for gas- and particle-phase chemistry, Atmos. Chem. Phys., 9, 5505-5518, doi:10.5194/acp-9-5505-2009, 2009.

Breitenlechner, M. and Hansel, A.: Development of an Advanced Selective Reagent Ionization Time of Flight Mass Spectrometer (advanced SRI-TOF-MS), Int. J. Mass Spectrom., submitted, 2015.

Caemmerer, S. and Farquhar, G. D.: Some relationships between the biochemistry of photosynthesis and the gas exchange of leaves, Planta, 153, 376-387, doi:10.1007/BF00384257, 1981.

Cape, J. N., Hamilton, R., and Heal, M. R.: Reactive uptake of ozone at simulated leaf surfaces: implications for "non-stomatal" ozone flux, Atmos. Environ., 43, 1116-1123, doi:10.1016/j.atmosenv.2008.11.007, 2009.

Chan, A. W. H., Kreisberg, N. M., Hohaus, T., Campuzano-Jost, P., Zhao, Y., Day, D. A., Kaser, L., Karl, T., Hansel, A., Teng, A. P., Ruehl, C. R., Sueper, D. T., Jayne, J. T., Worsnop, D. R., Jimenez, J. L., Hering, S. V., and Goldstein, A. H.: Speciated measurements of semivolatile and intermediate volatility organic compounds (S/IVOCs) in a pine forest during BEACHONRoMBAS 2011, Atmos. Chem. Phys. Discuss., 15, 2233122377, doi:10.5194/acpd-15-22331-2015, 2015.

Cieslik, S. A.: Ozone uptake by various surface types: a comparison between dose and exposure, Atmos. Environ., 38, 2409-2420, doi:10.1016/j.atmosenv.2003.10.063, 2004.

Criegee, R.: Mechanism of ozonolysis, Angew. Chem. Int. Edit., 14, 745-752, 1975.

D’Anna, B., Jammoul, A., George, C., Stemmler, K., Fahrni, S., Ammann, M., and Wisthaler, A.: Light-induced ozone depletion by humic acid films and submicron aerosol particles, J. Geophys. Res., 114, D12301, doi:10.1029/2008JD011237, 2009.

Dell, B. and McComb, A. J.: Plant Resins-Their Formation, Secretion and Possible Functions, Adv. Bot. Res., 6, 277-316, doi:10.1016/S0065-2296(08)60332-8, 1979.

Dentener, F., Stevenson, D., Ellingsen, K., Van Noije, T., Schultz, M., Amann, M., Atherton, C., Bell, N., Bergmann, D., Bey, I., Bouwman, L., Butler, T., Cofala, J., Collins, B., Drevet, J., Doherty, R., Eickhout, B., Eskes, H., Fiore, A., Gauss, M., Hauglustaine, D., Horowitz, L., Isaksen, I. S. A., Josse, B., Lawrence, M., Krol, M., Lamarque, J. F., Montanaro, V., Müller, J. F., Peuch, V. H., Pitari, G., Pyle, J., Rast, S., Rodriguez, J., Sanderson, M., Savage, N. H., Shindell, D., Strahan, S., Szopa, S., Sudo, K., Van Dingenen, R., Wild, O., and Zeng, G.: The global atmospheric environment for the next generation, Environ. Sci. Technol., 40, 3586-3594, doi:10.1021/es0523845, 2006.

Eltayeb, A. E., Kawano, N., Badawi, G. H., Kaminaka, H., Sanekata, T., Shibahara, T., Inanaga, S., and Tanaka, K.: Overexpression of monodehydroascorbate reductase in transgenic tobacco confers enhanced tolerance to ozone, salt and polyethylene glycol stresses, Planta, 225, 1255-1264, doi:10.1007/s00425006-0417-7, 2007.

Enzell, C. R., Wahlberg, I., and Ryhage, R.: Mass spectra of tobacco isoprenoids, Mass Spectrom. Rev., 3, 395-438, doi:10.1002/mas.1280030304, 1984

Estell, R. E., Fredrickson, E. L., Anderson, D. M., Mueller, W. F., and Remmenga, M. D.: Relationship of Tarbush Leaf Surface 
Secondary Chemistry to Livestock Herbivory, J. Range Manage., 47, 424-428, doi:10.2307/4002991, 1994a.

Estell, R. E., Havstad, K. M., Fredrickson, E. L., and GardeaTorresdey, J. L.: Secondary chemistry of the leaf surface of Flourensia cernua, Biochem. Syst. Ecol., 22, 73-77, doi:10.1016/0305-1978(94)90116-3, 1994b.

Fahn, A.: Secretory tissues in vascular plants, New Phytol., 108, 229-257, doi:10.1111/j.1469-8137.1988.tb04159.x, 1988.

Fares, S., McKay, M., Holzinger, R., and Goldstein, A. H.: Ozone fluxes in a Pinus ponderosa ecosystem are dominated by non-stomatal processes: Evidence from long-term continuous measurements, Agr. Forest Meteorol., 150, 420-431, doi:10.1016/j.agrformet.2010.01.007, 2010.

Fares, S., Weber, R., Park, J.-H., Gentner, D., Karlik, J., and Goldstein, A. H.: Ozone deposition to an orange orchard: partitioning between stomatal and non-stomatal sinks, Environ. Pollut., 169, 258-266, doi:10.1016/j.envpol.2012.01.030, 2012.

Felzer, B., Reilly, J., Melillo, J., Kicklighter, D., Sarofim, M., Wang, C., Prinn, R., and Zhuang, Q.: Future effects of ozone on carbon sequestration and climate change policy using a global biogeochemical model, Climatic Change, 73, 345-373, doi:10.1007/s10584-005-6776-4, 2005.

Fruekilde, P., Hjorth, J., Jensen, N., Kotzias, D., and Larsen, B.: Ozonolysis at vegetation surfaces, Atmos. Environ., 32, 18931902, doi:10.1016/S1352-2310(97)00485-8, 1998.

$\mathrm{Fu}$, Y. and Tai, A. P. K.: Impact of climate and land cover changes on tropospheric ozone air quality and public health in East Asia between 1980 and 2010, Atmos. Chem. Phys., 15, 10093-10106, doi:10.5194/acp-15-10093-2015, 2015.

Gilbert, M. D., Elfving, D. C., and Lisk, D. J.: Protection of plants against ozone injury using the antiozonant $\mathrm{N}$ (1,3-dimethylbutyl)-N'-phenyl-p-phenylenediamine, B. Environ. Contam. Tox., 18, 783-786, doi:10.1007/BF01691993, 1977.

Goldstein, A. H. and Galbally, I. E.: Known and Unexplored Organic Constituents in the Earth's Atmosphere, Environ. Sci. Technol., 41, 1514-1521, doi:10.1021/es072476p, 2007.

Goldstein, A. H., McKay, M., Kurpius, M. R., Schade, G. W., Lee, A., Holzinger, R., and Rasmussen, R. A.: Forest thinning experiment confirms ozone deposition to forest canopy is dominated by reaction with biogenic VOCs, Geophys. Res. Lett., 31, L22106, doi:10.1029/2004GL021259, 2004.

Granier, C., Bessagnet, B., Bond, T., D’Angiola, A., van der Gon, H. D., Frost, G. J., Heil, A., Kaiser, J. W., Kinne, S., Klimont, Z., Kloster, S., Lamarque, J. F., Liousse, C., Masui, T., Meleux, F., Mieville, A., Ohara, T., Raut, J. C., Riahi, K., Schultz, M. G., Smith, S. J., Thompson, A., van Aardenne, J., van der Werf, G. R., and van Vuuren, D. P.: Evolution of anthropogenic and biomass burning emissions of air pollutants at global and regional scales during the 1980-2010 period, Climatic Change, 109, 163-190, doi:10.1007/s10584-011-0154-1, 2011.

Graus, M., Müller, M., and Hansel, A.: High resolution PTR-TOF: quantification and formula confirmation of VOC in real time, J. Am. Soc. Mass Spectr., 21, 1037-1044, doi:10.1016/j.jasms.2010.02.006, 2010.

Hansel, A., Singer, W., Wisthaler, A., Schwarzmann, M., and Lindinger, W.: Energy dependencies of the proton transfer reactions, Int. J. Mass Spectrom., 167-168, 697-703, doi:10.1016/S0168-1176(97)00128-6, 1997.
Heggestad, H. E.: Origin of Bel-W3, Bel-C and Bel-B tobacco varieties and their use as indicators of ozone, Environ. Pollut., 74, 264-291, doi:10.1016/0269-7491(91)90076-9, 1991.

Hewitt, C. N., Kok, G. L., and Fall, R.: Hydroperoxides in plants exposed to ozone mediate air pollution damage to alkene emitters, Nature, 344, 56-58, doi:10.1038/344056a0, 1990.

Himanen, S. J., Blande, J. D., Klemola, T., Pulkkinen, J., Heijari, J., and Holopainen, J. K.: Birch (Betula spp.) leaves adsorb and rerelease volatiles specific to neighbouring plants - a mechanism for associational herbivore resistance?, New Phytol., 186, 722732, doi:10.1111/j.1469-8137.2010.03220.x, 2010.

Holzinger, R., Lee, A., Paw, K. T., and Goldstein, U. A. H.: Observations of oxidation products above a forest imply biogenic emissions of very reactive compounds, Atmos. Chem. Phys., 5, 67-75, doi:10.5194/acp-5-67-2005, 2005.

IPCC: Climate Change 2013: The Physical Science Basis. Contribution of Working Group I to the Fifth Assessment Report of the Intergovernmental Panel on Climate Change, Cambridge University Press, Cambridge, United Kingdom and New York, NY, USA, 2013.

Isidorov, V. A., Vinogorova, V. T., and Rafałowski, K.: HSSPME analysis of volatile organic compounds of coniferous needle litter, Atmos. Environ., 37, 4645-4650, doi:10.1016/j.atmosenv.2003.07.005, 2003.

Jenkin, M. E. and Clemitshaw, K. C.: Ozone and other secondary photochemical pollutants: chemical processes governing their formation in the planetary boundary layer, Atmos. Environ., 34, 2499-2527, doi:10.1016/S1352-2310(99)00478-1, 2000.

Karl, T., Harley, P., Emmons, L., Thornton, B., Guenther, A., Basu, C., Turnipseed, A., and Jardine, K.: Efficient atmospheric cleansing of oxidized organic trace gases by vegetation, Science, 330, 816-819, doi:10.1126/science.1192534, 2010.

Karl, T., Hansel, A., Cappellin, L., Kaser, L., Herdlinger-Blatt, I., and Jud, W.: Selective measurements of isoprene and 2methyl-3-buten-2-ol based on $\mathrm{NO}^{+}$ionization mass spectrometry, Atmos. Chem. Phys., 12, 11877-11884, doi:10.5194/acp12-11877-2012, 2012.

Kennedy, B. S., Nielsen, M. T., Severson, R. F., Sisson, V. A., Stephenson, M. K., and Jackson, D. M.: Leaf surface chemicals from Nicotiana affecting germination of Peronospora tabacina (adam) sporangia, J. Chem. Ecol., 18, 1467-1479, doi:10.1007/BF00993221, 1992.

Kennedy, B. S., Nielsen, M. T., and Severson, R. F.: Biorationals from Nicotiana protect cucumbers against Colletotrichum lagenarium (Pass.) ell. \& halst disease development, J. Chem. Ecol., 21, 221-231, doi:10.1007/BF02036653, 1995.

Kurpius, M. R. and Goldstein, A. H.: Gas-phase chemistry dominates $\mathrm{O}_{3}$ loss to a forest, implying a source of aerosols and hydroxyl radicals to the atmosphere, Geophys. Res. Lett., 30, 1371, doi:10.1029/2002GL016785, 2003.

Laisk, A., Kull, O., and Moldau, H.: Ozone concentration in leaf intercellular air spaces is close to zero, Plant Physiol., 90, 11631167, 1989.

Landolt, W., Bühlmann, U., Bleuler, P., and Bucher, J. B.: Ozone exposure-response relationships for biomass and root/shoot ratio of beech (Fagus sylvatica), ash (Fraxinus excelsior), Norway spruce (Picea abies) and Scots pine (Pinus sylvestris), Environ. Pollut., 109, 473-478, doi:10.1016/S0269-7491(00)000506, 2000. 
Langenheim, J. H.: Plant Resins: Chemistry, Evolution, Ecology, and Ethnobotany, Timber Press, Portland, Cambridge, 2003.

Lin, Y. and Wagner, G. J.: Surface disposition and stability of pest-interactive, trichome-exuded diterpenes and sucrose esters of tobacco, J. Chem. Ecol., 20, 1907-1921, doi:10.1007/BF02066232, 1994.

Logan, J. A., Staehelin, J., Megretskaia, I. A., Cammas, J. P., Thouret, V., Claude, H., De Backer, H., Steinbacher, M., Scheel, H. E., Stbi, R., Frhlich, M., and Derwent, R.: Changes in ozone over Europe: Analysis of ozone measurements from sondes, regular aircraft (MOZAIC) and alpine surface sites, J. Geophys. Res.-Atmos., 117, 1-23, doi:10.1029/2011JD016952, 2012.

Loreto, F. and Fares, S.: Is ozone flux inside leaves only a damage indicator? Clues from volatile isoprenoid studies, Plant Physiol., 143, 1096-1100, doi:10.1104/pp.106.091892, 2007.

Loreto, F., Mannozzi, M., Maris, C., Nascetti, P., Ferranti, F., and Pasqualini, S.: Ozone quenching properties of isoprene and its antioxidant role in leaves, Plant Physiol., 126, 993-1000, doi:10.1104/pp.126.3.993, 2001

Massman, W. J.: Toward an ozone standard to protect vegetation based on effective dose: a review of deposition resistances and a possible metric, Atmos. Environ., 38, 2323-2337, doi:10.1016/j.atmosenv.2003.09.079, 2004.

Moldau, H. and Bichele, I.: Plasmalemma protection by the apoplast as assessed from above-zero ozone concentrations in leaf intercellular air spaces, Planta, 214, 484-487, doi:10.1007/s00425-001-0678-0, 2002.

Monson, R. and Baldocchi, D.: Terrestrial Biosphere-Atmosphere Fluxes, Cambridge University Press, New York, 2014.

Müller, M., Mikoviny, T., Jud, W., D'Anna, B., and Wisthaler, A.: A new software tool for the analysis of high resolution PTRTOF mass spectra, Chemometr. Intell. Lab., 127, 158-165, doi:10.1016/j.chemolab.2013.06.011, 2013.

Neubert, A., Kley, D., Wildt, J., Segschneider, H., and Förstel, H.: Uptake of $\mathrm{NO}, \mathrm{NO}_{2}$ and $\mathrm{O}_{3}$ by sunflower (Helianthus annuus L.) and tobacco plants (Nicotiana tabacum L.): dependence on stomatal conductivity, Atmos. Environ. A-Gen., 27, 21372145, doi:10.1016/0960-1686(93)90043-X, 1993.

Niinemets, Ü., Fares, S., Harley, P., and Jardine, K. J: Bidirectional exchange of biogenic volatiles with vegetation: Emission sources, reactions, breakdown and deposition, Plant Cell Environ., 37, 1790-1809, doi:10.1111/pce.12322, 2014.

Oltmans, S., Lefohn, A., Shadwick, D., Harris, J., Scheel, H., Galbally, I., Tarasick, D., Johnson, B., Brunke, E.-G., Claude, H., Zeng, G., Nichol, S., Schmidlin, F., Davies, J., Cuevas, E., Redondas, A., Naoe, H., Nakano, T., and Kawasato, T.: Recent tropospheric ozone changes - A pattern dominated by slow or no growth, Atmos. Environ., 67, 331-351, doi:10.1016/j.atmosenv.2012.10.057, 2013.

Ormeño, E., Céspedes, B., Sánchez, I. A., Velasco-García, A., Moreno, J. M., Fernandez, C., and Baldy, V.: The relationship between terpenes and flammability of leaf litter, Forest Ecol. Manag., 257, 471-482, doi:10.1016/j.foreco.2008.09.019, 2009.

Palm, B. B., Campuzano-Jost, P., Ortega, A. M., Day, D. A., Kaser, L., Jud, W., Karl, T., Hansel, A., Hunter, J. F., Cross, E. S., Kroll, J. H., Peng, Z., Brune, W. H., and Jimenez, J. L.: In situ secondary organic aerosol formation from ambient pine forest air using an oxidation flow reactor, Atmos. Chem. Phys. Discuss., 15, 30409-30471, doi:10.5194/acpd-15-30409-2015, 2015.
Palmer-Young, E. C., Veit, D., Gershenzon, J., and Schuman, M. C.: The Sesquiterpenes(E)- $\beta$-Farnesene and (E)- $\alpha$-Bergamotene Quench Ozone but Fail to Protect the Wild Tobacco Nicotiana attenuata from Ozone, UVB, and Drought Stresses, Plos One, 1-22, doi:10.5061/dryad.602d6, 2015.

Parrish, D. D., Law, K. S., Staehelin, J., Derwent, R., Cooper, O. R., Tanimoto, H., Volz-Thomas, A., Gilge, S., Scheel, H.-E., Steinbacher, M., and Chan, E.: Long-term changes in lower tropospheric baseline ozone concentrations at northern mid-latitudes, Atmos. Chem. Phys., 12, 11485-11504, doi:10.5194/acp-1211485-2012, 2012.

Rannik, Ü., Altimir, N., Mammarella, I., Bäck, J., Rinne, J., Ruuskanen, T. M., Hari, P., Vesala, T., and Kulmala, M.: Ozone deposition into a boreal forest over a decade of observations: evaluating deposition partitioning and driving variables, Atmos. Chem. Phys., 12, 12165-12182, doi:10.5194/acp-1212165-2012, 2012.

Rogge, W. F., Hildemann, L. M., Mazurek, M. A., Cass, G. R., and Simoneit, B. R. T.: Sources of fine organic aerosol. 4. Particulate abrasion products from leaf surfaces of urban plants, Environ. Sci. Technol., 27, 2700-2711, doi:10.1021/es00049a008, 1993.

Sallaud, C., Giacalone, C., Töpfer, R., Goepfert, S., Bakaher, N., Rösti, S., and Tissier, A.: Characterization of two genes for the biosynthesis of the labdane diterpene Z-abienol in tobacco (Nicotiana tabacum) glandular trichomes, Plant J., 72, 1-17, doi:10.1111/j.1365-313X.2012.05068.x, 2012.

Schmid, C., Steinbrecher, R., and Ziegler, H.: Partition coefficients of plant cuticles for monoterpenes, Trees, 6, 32-36, doi:10.1007/BF00224496, 1992.

Schnitzler, J. P., Langebartels, C., Heller, W., Liu, J., Lippert, M., Dohring, T., Bahnweg, G., and Sandermann, H.: Ameliorating effect of UV-B radiation on the response of Norway spruce and Scots pine to ambient ozone concentrations, Glob. Change Biol., 5, 83-94, doi:10.1046/j.1365-2486.1998.00208.x, 1999.

Schraudner, M., Moeder, W., Wiese, C., Van Camp, W., Inzé, D., Langebartels, C., and Sandermann, H.: Ozone-induced oxidative burst in the ozone biomonitor plant, tobacco Bel W3, Plant J., 16, 235-245, doi:10.1046/j.1365-313X.1998.00294.x, 1998.

Shi, S. and Zhao, B.: Estimating indoor semi-volatile organic compounds (SVOCs) associated with settled dust by an integrated kinetic model accounting for aerosol dynamics, Atmos. Environ., 107, 52-61, doi:10.1016/j.atmosenv.2015.01.076, 2015.

Singh, S. and Agrawal, S. B.: Impact of tropospheric ozone on wheat (Triticum aestivum L.) in the eastern Gangetic plains of India as assessed by ethylenediurea (EDU) application during different developmental stages, Agr. Ecosyst. Environ., 138, 214 221, doi:10.1016/j.agee.2010.04.020, 2010.

Sitch, S., Cox, P. M., Collins, W. J., and Huntingford, C.: Indirect radiative forcing of climate change through ozone effects on the land-carbon sink, Nature, 448, 791-794, doi:10.1038/nature06059, 2007.

Španěl, P., Ji, Y., and Smith, D.: SIFT studies of the reactions of $\mathrm{H}_{3} \mathrm{O}^{+}, \mathrm{NO}^{+}$and $\mathrm{O}_{2}^{+}$with a series of aldehydes and ketones, Int. J. Mass Spectrom., 165-166, 25-37, doi:10.1016/S01681176(97)00166-3, 1997.

Thimmappa, R., Geisler, K., Louveau, T., O’Maille, P., and Osbourn, A.: Triterpene biosynthesis in plants, Annu. Rev. Plant Biol., 65, 225-257, doi:10.1146/annurev-arplant-050312120229, 2014. 
Van Dingenen, R., Dentener, F. J., Raes, F., Krol, M. C., Emberson, L., and Cofala, J.: The global impact of ozone on agricultural crop yields under current and future air quality legislation, Atmos. Environ., 43, 604-618, doi:10.1016/j.atmosenv.2008.10.033, 2009.

Vickers, C. E., Gershenzon, J., Lerdau, M. T., and Loreto, F.: A unified mechanism of action for volatile isoprenoids in plant abiotic stress, Nat. Chem. Biol., 5, 283-291, doi:10.1038/nchembio.158, 2009a.

Vickers, C. E., Possell, M., Cojocariu, C. I., Velikova, V. B., Laothawornkitkul, J., Ryan, A., Mullineaux, P. M., and Hewitt, C. N.: Isoprene synthesis protects transgenic tobacco plants from oxidative stress, Plant Cell Environ., 32, 520-31, doi:10.1111/j.13653040.2009.01946.x, 2009b.

Vingarzan, R.: A review of surface ozone background levels and trends, Atmos. Environ., 38, 3431-3442, doi:10.1016/j.atmosenv.2004.03.030, 2004.

Wagner, G. J.: Secreting glandular trichomes: more than just hairs, Plant Physiol., 96, 675-679, 1991.

Wagner, G. J., Wang, E., and Shepherd, R. W.: New Approaches for Studying and Exploiting an Old Protuberance, the Plant Trichome, Ann. Bot., 93, 3-11, doi:10.1093/aob/mch011, 2004.

Wang, X. and Mauzerall, D. L.: Characterizing distributions of surface ozone and its impact on grain production in China, Japan and South Korea: 1990 and 2020, Atmos. Environ., 38, 43834402, doi:10.1016/j.atmosenv.2004.03.067, 2004.

Weiss, P.: Vegetation/Soil Distribution of Semivolatile Organic Compounds in Relation to Their Physicochemical Properties, Environ. Sci. Technol., 34, 1707-1714, doi:10.1021/es990576s, 2000.

Weschler, C. J., Wisthaler, A., Cowlin, S., Tamás, G., Strøm Tejsen, P., Hodgson, A. T., Destaillats, H., Herrington, J., Zhang, J., and Nazaroff, W. W.: Ozone-initiated chemistry in an occupied simulated aircraft cabin, Environ. Sci. Technol., 41, 6177-6184, doi:10.1021/es0708520, 2007.
Wisthaler, A. and Weschler, C. J.: Reactions of ozone with human skin lipids: sources of carbonyls, dicarbonyls, and hydroxycarbonyls in indoor air, P. Natl. Acad. Sci. USA, 107, 6568-6575, doi:10.1073/pnas.0904498106, 2010.

Wisthaler, A., Tamás, G., Wyon, D. P., Strøm Tejsen, P., Space, D., Beauchamp, J., Hansel, A., Märk, T. D., and Weschler, C. J.: Products of ozone-initiated chemistry in a simulated aircraft environment, Environ. Sci. Technol., 39, 4823-4832, doi:10.1021/es047992j, 2005.

Wohlfahrt, G., Hörtnagl, L., Hammerle, A., Graus, M., and Hansel, A.: Measuring eddy covariance fluxes of ozone with a slow-response analyser, Atmos. Environ., 43, 4570-4576, doi:10.1016/j.atmosenv.2009.06.031, 2009.

Wohlgemuth, H., Mittelstrass, K., Kschieschan, S., Bender, J., Weigel, H.-J., Overmyer, K., Kangasjarvi, J., Sandermann, H., and Langebartels, C.: Activation of an oxidative burst is a general feature of sensitive plants exposed to the air pollutant ozone, Plant Cell Environ., 25, 717-726, doi:10.1046/j.13653040.2002.00859.x, 2002.

Wolfe, G. M., Thornton, J. A., Bouvier-Brown, N. C., Goldstein, A. H., Park, J.-H., McKay, M., Matross, D. M., Mao, J., Brune, W. H., LaFranchi, B. W., Browne, E. C., Min, K.-E., Wooldridge, P. J., Cohen, R. C., Crounse, J. D., Faloona, I. C., Gilman, J. B., Kuster, W. C., de Gouw, J. A., Huisman, A., and Keutsch, F. N.: The Chemistry of Atmosphere-Forest Exchange (CAFE) Model - Part 2: Application to BEARPEX-2007 observations, Atmos. Chem. Phys., 11, 1269-1294, doi:10.5194/acp-11-12692011, 2011a.

Wolfe, G. M. and Thornton, J. A.: The Chemistry of AtmosphereForest Exchange (CAFE) Model - Part 1: Model description and characterization, Atmos. Chem. Phys., 11, 77-101, doi:10.5194/acp-11-77-2011, 2011 b. 